\title{
Cardiac hormones for the treatment of cancer
}

\section{David L Vesely}

Division of Endocrinology, Diabetes and Metabolism, Departments of Medicine, Molecular Pharmacology and Physiology, James A. Haley VA Medical Center-151, University of South Florida Cardiac Hormone Center, and University of South Florida Morsani School of Medicine, 13000 Bruce B. Downs Boulevard, Tampa, Florida 33612, USA
Correspondence should be addressed to D L Vesely Email david.vesely@va.gov

\begin{abstract}
Four cardiac hormones, namely atrial natriuretic peptide, vessel dilator, kaliuretic peptide, and long-acting natriuretic peptide, reduce up to $97 \%$ of all cancer cells in vitro. These four cardiac hormones eliminate up to $86 \%$ of human small-cell lung carcinomas, two-thirds of human breast cancers, and up to $80 \%$ of human pancreatic adenocarcinomas growing in athymic mice. Their anticancer mechanisms of action, after binding to specific receptors on cancer cells, include targeting the rat sarcoma-bound GTP (RAS) (95\% inhibition)mitogen-activated protein kinase kinase 1/2 (MEK 1/2) (98\% inhibition)-extracellular signal-related kinase $1 / 2$ (ERK 1/2) (96\% inhibition) cascade in cancer cells. They also inhibit MAPK9, i.e. c-Jun $\mathrm{N}$-terminal kinase 2. They are dual inhibitors of vascular endothelial growth factor (VEGF) and its VEGFR2 receptor (up to $89 \%$ ). One of the downstream targets of VEGF is $\beta$-catenin, which they reduce up to $88 \%$. The WNT pathway is inhibited up to $68 \%$ and secreted frizzled-related protein 3 decreased up to $84 \%$ by the four cardiac hormones. AKT, a serine/threonine protein kinase, is reduced up to $64 \%$ by the cardiac hormones. STAT3, a final 'switch' that activates gene expression that leads to malignancy, is decreased by up to $88 \%$ by the cardiac hormones. STAT3 is specifically decreased as they do not affect STAT1. There is a cross-talk between the RAS-MEK 1/2-ERK 1/2 kinase cascade, VEGF, $\beta$-catenin, WNT, JNK, and STAT pathways and each of these pathways is inhibited by the cardiac hormones.
\end{abstract}
Key Words
- cancer
- hormones
- RAS
- $\beta$-catenin

Endocrine-Related Cancer (2013) 20, R113-R125

\section{Introduction}

The heart is a sophisticated endocrine gland that synthesizes at least six peptide hormones by three different genes (Brenner et al. 1990, Gardner et al. 1997, Vesely 2002). The cardiac hormones synthesized by these three genes are stored as three different prohormones, namely the 126 amino acid (a.a.) atrial natriuretic peptide (ANP), 108 a.a. brain natriuretic peptide (BNP), and 103 a.a. C-type natriuretic peptide (CNP) prohormones (Brenner et al. 1990, Gardner et al. 1997, Vesely 2002).
Within the 126 a.a. ANP prohormone are four peptide hormones (Fig. 1). The main physiological properties of these four peptide hormones after their release from the heart are blood pressure regulation and the maintenance of plasma volume in animals (Vesely et al. 1987, Martin et al. 1990, Gunning et al. 1992, Benjamin \& Peterson 1995, Zeidel 1995, Villarreal et al. 1999, Dietz et al. 2001) and humans (Vesely et al. 1994a,b, 1998). The cardiac hormones, synthesized in the atrium of the heart, are 


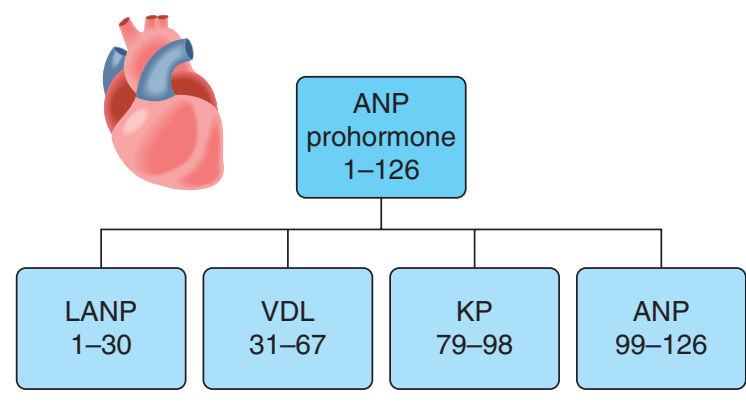

\section{Figure 1}

The atrial natriuretic peptide (ANP) gene in the heart codes for a 126 amino acid (a.a.) prohormone which through proteolytic processing results in the formation of the four cardiac hormones. These four cardiac hormones are: long-acting natriuretic peptide (LANP), consisting of the first 30 a.a. from the $\mathrm{N}$-terminus of the 126 a.a. prohormone; vessel dilator (VDL), consisting of a.a. 31-67 of the prohormone; kaliuretic peptide (KP), consisting of a.a. 79-98 of this prohormone; and ANP, consisting of a.a. 99-126 of the 126 a.a. prohormone. Reprinted with permission from Sun Y, Eichelbaum EJ, Wang H \& Vesely DL 2006a Vessel dilator and kaliuretic peptide inhibit activation of ERK $1 / 2$ in human prostate cancer cells. Anticancer Research 26 3217-3222.

long-acting natriuretic peptide (LANP) that consists of the first 30 a.a. from the N-terminal end of the ANP prohormone; vessel dilator, a.a. 31-67; kaliuretic peptide, a.a. 79-98; and ANP, a.a. 99-126 of the 126 a.a. prohormone (Vesely 1992, 2002; Fig. 1). The BNP and CNP genes, on the other hand, appear to each synthesize only one peptide hormone within their respective hormones, namely BNP and CNP (Gardner et al. 1997, Lainchbury et al. 1997, Scotland et al. 2005). Each of these peptide hormones circulates in humans and animals (Vesely et al. 1989, Winters et al. 1989, Hunter et al. 1998, De Palo et al. 2000, Franz et al. 2000, 2001, Vesely 2003, Cataliotti \& Burnett 2005). When these four cardiac hormones synthesized by the ANP prohormone gene are given in concentrations higher than those synthesized by the heart, they have anticancer effects on human pancreatic cancers growing in athymic mice (Vesely et al. $2007 a, c)$. BNP does not appear to have any anticancer effects (Gower et al. 2005, Vesely et al. 2005a,b, 2006c, $2007 b, d)$. CNP has anticancer effects in vitro but only when given in 100-fold higher concentrations than the above four cardiac hormones synthesized by the ANP prohormone gene (Vesely et al. 2005b, 2006c). This review will concentrate on the four cardiac hormones from the ANP prohormone and their anticancer effects.

All of the effects of the cardiac hormones on cancer appear to be mediated via the intracellular messenger cyclic GMP formed by enhancing the enzyme guanylate cyclase, which is part of natriuretic peptide receptor-A
(NPR-A; Fig. 2; Vesely 1992). Guanylate cyclase converts GTP to cyclic GMP (Waldman et al. 1984). Cyclic GMP has a strong anticancer effect of decreasing human pancreatic cancer cell volume in vivo by $95 \%$ (Vesely et al. 2004). Cyclic GMP inhibits the activation of kinases in the Ras-MEK 1/2-ERK 1/2 kinase cascade that mediate the growth of cancers (Fig. 3). Thus, cyclic GMP blocks the conversion of inactive Ras-GDP to active Ras-GTP by $89 \%$ (Sun et al. 2009b), inhibits the phosphorylation of MEK $1 / 2$ kinases by $93 \%$ (Sun et al. 2007b), and inhibits $83 \%$ of the phosphorylation of ERK 1/2 kinases (Sun et al. 2006b).

Because guanylate cyclase is part of the NRP-A receptor itself (Fig. 2), one would expect that the stimulation of the NPR-A receptor would inhibit the proliferation and growth of cancer cells via increasing cyclic GMP. With respect to this, knockout of the NPR-A receptor results in no growth of implanted cancer cells in mice (Wang et al. 2011). The NPR-C receptor, on the other hand, does not contain guanylate cyclase as the NPR-A

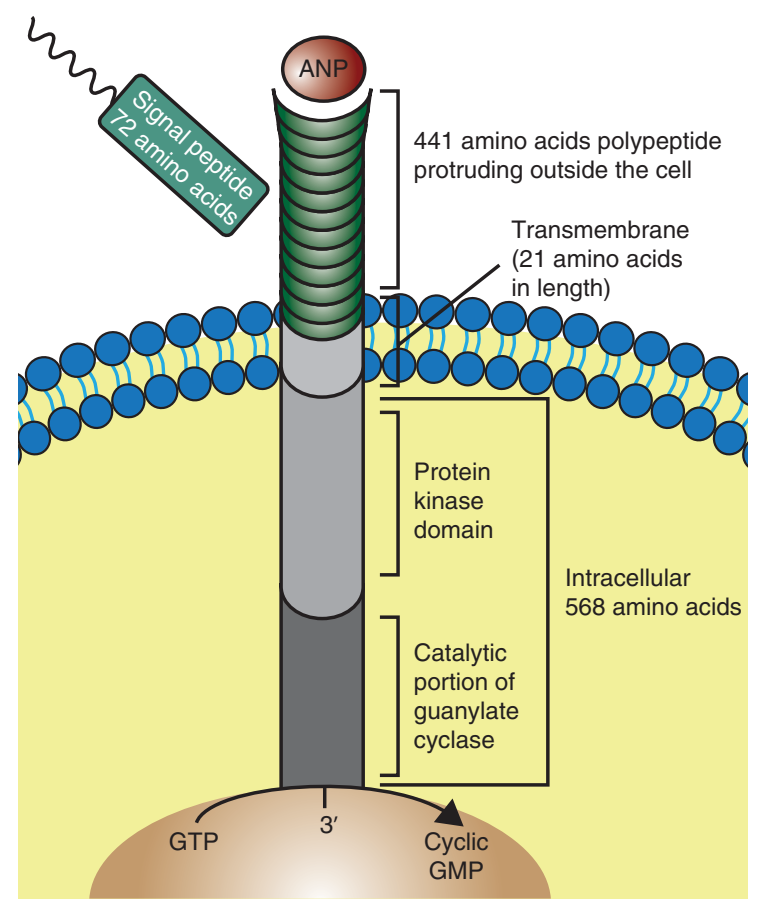

Figure 2

Structure of natriuretic peptide receptor-A (NPR-A, active receptor). The extracellular portion of the receptor (441 amino acids) binds atrial natriuretic peptide (ANP) from the circulation, which activates the catalytic portion of guanylate cyclase within the receptor itself on the inside of the cell membrane and then catalyzes the conversion of GTP to the intracellular messenger cyclic GMP. The structure illustrated was drawn utilizing the amino acid sequences determined for the NPR-A receptor. Reprinted with permission of Vesely DL 1992 Atrial Natriuretic Hormones, pp 1-256. Englewood Cliffs, New Jersey: Prentice Hall. 


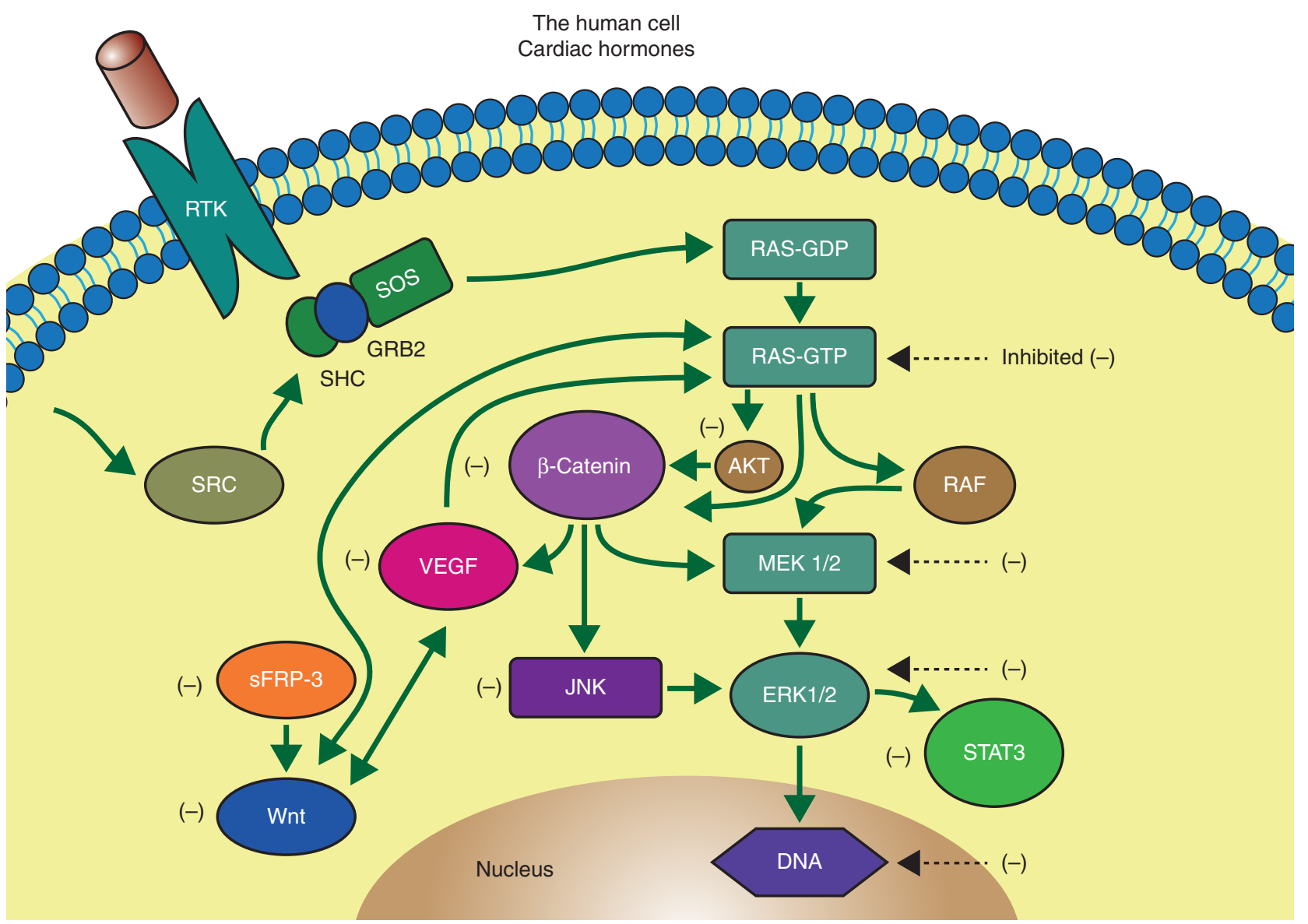

\section{Figure 3}

Cardiac hormones inhibit RAS-GTP, MEK $1 / 2$, and ERK $1 / 2$ kinases of the RAS-MEK 1/2-ERK $1 / 2$ kinase cascade by $95-98 \%$. These multiple kinase inhibitors are also strong inhibitors (i.e. $91 \%$ ) of DNA synthesis within cancer cells. Other targets which the cardiac hormones inhibit within cancer cells are VEGF, the VEGFR2 receptor, $\beta$-catenin, secreted frizzled receptor, JNK, STAT3, and the WNT pathway. RTK, tyrosine kinase receptor; SRC, rous sarcoma viral proto-oncogene tyrosine kinase; SHC, rous sarcoma SH2 C-terminal binding domain adapter protein; GRB2, growth factor receptor-bound protein 2; SOS, son of sevenless gene; RAS-GDP, rat sarcoma-bound GDP; RAS-GTP, rat sarcoma-bound GTP; RAF, rapidly accelerated fibrosarcoma serine/threonine protein kinase; MOS, Moloney murine sarcoma virus serine/threonine protein kinase; MEK 1/2, mitogenactivated protein kinase kinase 1/2; ERK 1/2, extracellular signal-related kinases 1/2; VEGF, vascular endothelial growth factor; sFRP-3, secreted frizzled-related protein-3; JNK, c-Jun N-terminal kinases; AKT, AK mouse strain with ' $t$ ' for thymoma. Modified with permission from Sun $Y$, Eichelbaum EJ, Lenz A, Wang H \& Vesely DL 2010 Epidermal growth factor's activation of RAS is inhibited by four cardiac hormones. European Journal of Clinical Investigation 40 408-413.

does appear that all of the anticancer effects of the cardiac hormones are mediated by cyclic GMP, the abilities of vessel dilator and kaliuretic peptide to cause a natriuresis are not mediated by cyclic GMP but rather via enhancing prostaglandin $\mathrm{E}_{2}$, which is synthesized secondary to vessel dilator and kaliuretic peptide (Gunning et al. 1992, Chiou \& Vesely 1995). The ability of prostaglandin $\mathrm{E}_{2}$ to downregulate the NPR-C receptor, i.e. the clearance receptor for clearing ANP (Gower et al. 2006), should result in less clearance of ANP, thus allowing more circulating ANP to stimulate the NPR-A receptor as a possible mechanism of how the NPR-C receptor may help decrease cell proliferation. http://erc.endocrinology-journals.org DOI: 10.1530/ERC-13-0054
(C) 2013 Society for Endocrinology Printed in Great Britain 


\section{Anticancer effects of the cardiac hormones in vitro}

LANP, vessel dilator, kaliuretic peptide, and ANP decrease the number, i.e. eliminate, up to $97 \%$ of pancreatic (Vesely et al. 2003), breast (Vesely et al. 2005b), colon (Gower et al. 2005), kidney (Vesely et al. 2006c), prostate (Vesely et al. 2005a), ovarian (Vesely et al. 2007b,d), smallcell lung (Vesely et al. 2005b), and squamous cell lung carcinoma cells in vitro (Vesely et al. 2006b). In addition, they decrease glioblastomas of the brain (Vesely et al. $2007 a, c)$, medullary thyroid carcinomas (Eichelbaum et al. 2006), and angiosarcoma of the heart (Vesely et al. 2006a). There is no proliferation of the cancer cells that are not eliminated when examined for 3 days following the elimination of other cancer cells secondary to the cardiac hormones (Vesely et al. 2005a). ANP also decreases hepatoblastoma cells in culture (Rashed et al. 1993); however, the other cardiac hormones have not been investigated for their effects upon hepatoblastoma cells in culture. Serafino et al. (2012) have confirmed that ANP has an antiproliferative effect on cancer cells in their examination of colorectal cancer cells.

Dose-response investigations indicate that BNP has no anticancer effects at any concentration (Gower et al. 2005, Vesely et al. 2005a,b, 2006c, 2007b, d). The addition of BNP for $24 \mathrm{~h}$ results in a 1,2 , and $4 \%$ (all nonsignificant) decrease in renal carcinoma cell numbers at its 1,10 , and $100 \mu \mathrm{M}$ concentrations (Vesely et al. 2006c). CNP only has anticancer effects at 100-fold higher concentrations than that observed for the four cardiac hormones synthesized by the proANP gene (Vesely et al. $2005 b, 2006 c)$.

\section{Cardiac hormones eliminate up to $80 \%$ of human pancreatic adenocarcinomas in vivo}

Patients with human pancreatic adenocarcinomas have the lowest 5-year survival rate (1\%) for all common types of cancers (Pitchumoni 1998, Wolff et al. 2010). The mean survival is only 4 months with pancreatic cancer (Pitchumoni 1998, Wolff et al. 2010). S.c. administration of the cardiac hormones for 28 days in athymic mice bearing human pancreatic adenocarcinomas results in ANP eliminating $80 \%$ of the human pancreatic carcinomas (Table 1 ; Vesely et al. 2007a,c). With each of the cardiac hormones, when human pancreatic adenocarcinomas are eliminated, they never recur in the primary site in the lifespan of mice (Vesely et al. 2007a,c). Metastatic lesions can also be eliminated by utilizing a different cardiac hormone from
Table 1 Ability of the cardiac hormones to eliminate human cancers growing in athymic mice.

\begin{tabular}{|c|c|c|c|}
\hline & $\begin{array}{c}\text { Breast } \\
\text { cancer }(\%)\end{array}$ & $\begin{array}{c}\text { Pancreatic } \\
\text { adenocarcinoma }(\%)\end{array}$ & $\begin{array}{l}\text { Small-cell lung } \\
\text { cancer }(\%)\end{array}$ \\
\hline VDL & 67 & 33 & 71 \\
\hline LANP & 50 & 20 & 86 \\
\hline ANP & 33 & 80 & 43 \\
\hline $\mathrm{KP}$ & 67 & 14 & 57 \\
\hline
\end{tabular}

The values are the percentages of human carcinomas eliminated and which never recur in the primary site in athymic mice when treated with each of the cardiac hormones for 28 days at $3 \mathrm{nM} / \mathrm{kg}$ body weight per min. VDL, vessel dilator; LANP, long-acting natriuretic peptide; ANP, atrial natriuretic peptide; KP, kaliuretic peptide.

the one utilized to treat the primary lesion (Vesely et al. $2007 a, c)$

\section{Cardiac hormones eliminate up to $86 \%$ of human small-cell lung carcinomas in mice}

The cardiac hormones can eliminate up to $86 \%$ of human small-cell lung carcinomas growing in athymic mice (Table 1; Eichelbaum et al. 2008). The treated small-cell lung carcinomas that are not eliminated grow rapidly, similar to the untreated controls. Metastatic small-cell lung cancers can be eliminated using these cardiac hormones in a sequential manner, one after the other, each for 4 weeks (Eichelbaum et al. 2008).

\section{Cardiac hormones eliminate two-thirds of human breast carcinomas without any surgery}

Vessel dilator and KP each eliminate $67 \%$ of human breast adenocarcinomas in athymic mice (Table 1 ) when infused subcutaneously for 28 days (Vesely et al. 2007b, $d$ ). There is no recurrence of breast cancer at the primary site in the 12-month post-treatment period (Vesely et al. 2007b,d). The respective abilities of the four cardiac hormones to eliminate different types of cancers vary with the type of cancer, as illustrated in Table 1.

\section{Comparison of a twice-weekly i.v. treatment of pancreatic cancer for 4 weeks vs continuous treatment with ANP and vessel dilator for 4 weeks}

To determine whether the cardiac hormones have beneficial effect(s) when given less frequently to mice with human pancreatic cancer, the animals were treated with vessel dilator or ANP twice weekly for 4 weeks with

Published by Bioscientifica Ltd. 
$100 \mu \mathrm{M}$ bolus infusions via a vascular port (Lenz et al. 2010). Vessel dilator with the biweekly bolus eliminated one-third of human pancreatic adenocarcinomas. Biweekly ANP eliminated one in six of human pancreatic adenocarcinomas in athymic mice (Lenz et al. 2010).

The marked difference between the biweekly infusions for 4 weeks (Lenz et al. 2010) and the continuous s.c. infusion of the cardiac hormones for 4 weeks (Vesely et al. $2007 a, c)$ is that the biweekly treated pancreatic cancers that were not eliminated continued to grow and became very large as opposed to the continuous 28-day s.c. treatment with vessel dilator where the tumors that were not eliminated decreased in volume to $2-10 \%$ of that of untreated pancreatic carcinomas (Vesely et al. 2007a,c). This huge difference $(P<0.0001)$ in the outcome of the treatment with the twice-weekly i.v. infusion for 4 weeks vs continuous s.c. infusions for 4 weeks suggest that the preferred treatment would be via s.c. infusion for 4 weeks for both cardiac hormones.

\section{Mechanism of action of the cardiac hormones within cancer cells: receptors}

The above-listed human cancer cells each have cardiac hormone receptors to mediate their effects (Gower et al. 2005, Vesely et al. 2005a,b,c, 2006c). Western blot analysis revealed the presence of the ANP receptors (NPR)-A (Fig. 2) and -C (Vesely et al. 2005c). NPR-A (Fig. 2) is an interesting receptor, since in addition to having a 441 a.a. binding site extending outside the cell membrane to bind ANP, it also has a protein kinase and guanylate cyclase as part of the receptor itself. Guanylate cyclase within the receptor catalyzes the formation of the intracellular mediator cyclic GMP which mediates the effects of these cardiac hormones within cancer cells as discussed below.

\section{Metabolic targets of the cardiac hormones within cancer cells}

\section{RAS-MEK 1/2-ERK 1/2 kinase cascade}

Inside the cancer cells, the cardiac hormones have multiple targets (Fig. 3). The cardiac hormones are multi-kinase inhibitors that inhibit the rat sarcoma-bound GTP (RAS)mitogen-activated protein kinase kinase (MEK 1/2)-extracellular signal-related kinase (ERK 1/2) cascade pathway (Fig. 3; Sun et al. 2009a,b). This pathway is aberrantly activated in many types of neoplasms, with this activation being associated with a poor prognosis (Scholl et al. 2005,
McCubrey et al. 2007, 2008). These cardiac hormones inhibit this pathway at several steps as follows.

\section{RAS}

RAS has frequent structural alterations in cancer cells, which makes RAS a difficult treatment target for cancer (McCubrey et al. 2007, Sebolt-Leopold 2008). Targeting RAS by interfering with son of sevenless gene (SOS) or growth factor receptor-bound 2 (GRB2; Fig. 3) has not yielded viable drug development candidates (SeboltLeopold 2008). Inhibitors of farnesyltransferase as a means of preventing the membrane localization of RAS have inhibited this prenylation enzyme; however, cancer cells have proven to be impervious to the action of this class of inhibitors (Sebolt-Leopold 2008). Thus, there is a need for a new agent(s) that can inhibit active RAS-GTP (Sebolt-Leopold 2008).

Vessel dilator and kaliuretic peptide inhibit the conversion of inactive RAS-GDP to active RAS-GTP by 95 and $90 \%$ respectively, with this inhibition lasting for 48 $72 \mathrm{~h}$ (Sun et al. 2009a). Likewise, ANP and LANP inhibit the conversion of RAS-GDP to active RAS-GTP by 90 and 83\% (Sun et al. 2009b). They inhibit the conversion to active RAS within 5 min (Sun et al. 2009b). With respect to what mediates their inhibitory action on RAS, it has been found that an antibody to cyclic GMP added with the four cardiac hormones and cyclic GMP itself inhibits RAS-GTP activation (up to 89\%) (Sun et al. 2009a,b), suggesting that cyclic GMP mediates their inhibitory effects on RAS (Sun et al. 2009c, 2010). The four cardiac hormones also inhibit the stimulation of RAS by mitogens such as epidermal growth factor (EGF) and insulin.

\section{MEK 1/2 kinases}

The next step in the RAS-MEK 1/2-ERK 1/2 kinase cascade involves two kinases named MEK 1 and MEK 2 (Fig. 3). With respect to these two kinases, the protype member, i.e. mitogen-activated protein kinase kinase (MKK-1) or MEK 1, specifically phosphorylates threonine and tyrosine residues present in the Thr-Glu-Tyr sequence of extracellular signal-regulated kinases 1 and 2 (ERK 1/2; Crews et al. 1992, Wu et al. 1993). A second MEK family member, i.e. MEK 2, resembles MEK 1 in phosphorylating ERK 1/2 but is seven residues longer than MEK 1 with its amino acid sequence being $81 \%$, identical to MEK 1 (Wu et al. 1993). Vessel dilator, kaliuretic peptide, ANP, and LANP inhibit the phosphorylation of MEK $1 / 2$ kinases (Fig. 3) by $98,81,88$, and $97 \%$ respectively (Sun et al. 2007a,b).

Published by Bioscientifica Ltd. 
The inhibition of MEK 1/2 kinases by the four cardiac hormones is maximal at $2 \mathrm{~h}$ (Sun et al. 2007a,b). With respect to what mediates their inhibitory effect, it has been found that MEK $1 / 2$ kinases are also inhibited, as with RAS, by an antibody against cyclic GMP when added with the four cardiac hormones and cyclic GMP itself, inhibiting MEK $1 / 2$ phosphorylation by $93 \%$ (Sun et al. 2007a,b).

\section{Inhibition of ERK 1/2 kinases}

ERK 1/2 are MEKs that are important targets for inhibiting the growth of cancer(s) (Davis 2000, Schlessinger 2000). Growth factors such as EGF and vascular endothelial growth factor (VEGF) mediate their cancer-causing effects via ERK $1 / 2$ kinase activity (Schlessinger 2000). ERK 1/2 kinases can directly translocate to the nucleus and stimulate the production of several nuclear oncogenes such as c-fos (FOS; Davis 2000, Schlessinger 2000).

Vessel dilator, kaliuretic peptide, ANP, and LANP inhibit the phosphorylation of ERK 1/2 kinases by 96, 70, 94, and 88\% (Sun et al. 2006a,b). Each has significant effects within $5 \mathrm{~min}$ and lasts for at least $2 \mathrm{~h}$ (Sun et al. $2006 a, b)$. Thus, the cardiac hormones are multiple kinase inhibitors inhibiting the basal activity of each step in the RAS-MEK 1/2-ERK 1/2 kinase cascade in human cancer cells, as illustrated in Fig. 3.

\section{Mitogens such as EGF's stimulation of RAS and ERK 1/2 kinases are also blocked by the cardiac hormones}

EGF has been shown to directly activate RAS (Kamada \& Feramisco 1984, Satoh et al. 1990, Qui \& Green 1991, Medema et al. 1992). Vessel dilator, LANP, ANP, and kaliuretic peptide reduce EGF-stimulated active RAS-GTP by $73,79,33$, and $45 \%$ (Sun et al. 2010). The four cardiac hormones also inhibit up to $94 \%$ of the insulin-mediated conversion of RAS-GDP to active RAS-GTP (Sun et al. 2009 c) that contributes to cancer formation (Ceresa \& Pessin 1998).

EGF and insulin also stimulate ERK 1/2 kinases to cause cancer growth (Davis 2000, Schlessinger 2000). Insulin $(1 \mu \mathrm{M})$ and EGF $(10 \mathrm{ng} / \mathrm{ml})$ each enhance the phosphorylation of ERK $1 / 2$ kinases in pancreatic adenocarcinoma cells by 98 and $72 \%$ respectively (Sun et al. 2007c). This enhanced phosphorylation of ERK $1 / 2$ by EGF and insulin is decreased up to $51 \%$ below non-stimulated (basal) ERK $1 / 2$ activity by the four cardiac hormones (Sun et al. 2007c).

\section{Cardiac hormones' ability to decrease the volume of pancreatic cancers and inhibit RAS, MEK 1/2, and ERK 1/2 kinases is mediated by the intracellular messenger cyclic GMP}

Cyclic GMP is the intracellular messenger of the cardiac hormones for some of their biological effects such as blood pressure regulation (Vesely 1977, Waldman et al. 1984). Evidence showing that cyclic GMP itself has strong anticancer effects is that cyclic GMP decreases the volume of human pancreatic cancer cells in vivo by $95 \%$ (Vesely et al. 2004).

Further evidence of cyclic GMP mediating the anticancer effects of the cardiac hormones suggests that a cyclic GMP antibody added to the cardiac hormones inhibits the ability of these hormones to block the basal activity of RAS (Sun et al. 2009a,b), MEK 1/2 (Sun et al. $2007 a, b$ ), and ERK $1 / 2$ kinases (Sun et al. 2006a,b). Cyclic GMP itself inhibits the activation of RAS-GTP by $89 \%$ (Sun et al. 2009b), the phosphorylation of MEK 1/2 kinases by $93 \%$ (Sun et al. 2007b), and the phosphorylation of ERK 1/2 kinases by $83 \%$ (Sun et al. 2006b). Cyclic GMP, thus, appears to be very important for mediating the anticancer effects of these cardiac hormones in each step of the RAS-MEK 1/2-ERK 1/2 kinase cascade, as shown in Fig. 3.

\section{c-Jun $\mathrm{N}$-terminal kinases}

c-Jun N-terminal kinase-2 (JNK) is associated with cancer development (Dann et al. 2001, Malbon 2004) and the invasion of cancers (Juneja et al. 2011). Lung cancer cell growth (Bost et al. 1997), prostate cancer proliferation, and prostate cancer growth are dependent upon JNK2 (Bost et al. 1999a,b, Yang et al. 2003). JNK-2 is activated by a variety of extracellular growth factors such as EGF (Kyriakas et al. 1994, Rosette \& Karin 1996, Heasley \& Han 2006). The activation of JNK by EGF is dependent upon H-RAS activation (Derijard et al. 1994, Bost et al. 1997). The loss of JNK activation coupled with the loss of ERK activation promotes cell death (Xia et al. 1995). As part of the cross-talk among these kinases, JNK is activated by MEK kinases (Fig. 3; Minden et al. 1994).

ANP and vessel dilator maximally reduce the expression of JNK2 by $89 \%$, while LANP and kaliuretic peptide decrease JNK2 by 88 and $77 \%$ respectively in human small-cell lung cancer cells (Lane et al. 2012b). In human prostate adenocarcinoma cells, JNK2 was decreased by up to $84 \%$ by the four cardiac hormones (Lane et al. 2012b).

Published by Bioscientifica Ltd. 


\section{Vascular endothelial growth factor}

VEGF plays an essential role throughout tumor development by enabling the blood vessels to establish and grow into tumors, thereby providing nutrients and oxygen to the tumor (Folkman 1971, 2007, Liotta et al. 1974, Ferrara 2004, Hoeben et al. 2004). VEGF intracellularly enables cancer cells to grow via stimulating RAS (Doanes et al. 1999, Meadows et al. 2001), MEK 1/2 (Byrne et al. 2005, Wang et al. 2009), and ERK 1/2 kinases (Gupta et al. 1999, Breslin et al. 2003). VEGFR2/KDR/Flk-1 is the main VEGF receptor mediating the cancer-enhancing effects of VEGF (McMahon 2000, Ferrara 2004, Hoeben et al. 2004). The cardiac hormones are dual inhibitors of VEGF and its receptor VEGFR2 as outlined below.

The four cardiac hormones maximally decrease the VEGFR2 receptor in human pancreatic adenocarcinoma cells up to $83 \%$ (Nguyen et al. 2012). These four cardiac hormones decrease the VEGFR2 receptor by up to $89 \%$ in human small-cell lung cancer cells and up to $92 \%$ in human prostate cancer cells (Nguyen et al. 2012). These results were confirmed by Western blot that revealed a cardiac hormone-mediated decrease in VEGFR2 receptor (Nguyen et al. 2012). The cardiac hormones reduce VEGF concentrations up to 58\% (Nguyen et al. 2012). Although there are a number of compounds that inhibit VEGF or its VEGFR2 receptor, the cardiac hormones are the first agents that are dual inhibitors of VEGF and its VEGFR2 receptor (Nguyen et al. 2012).

\section{$\beta$-Catenin}

One of the downstream targets of VEGF is $\beta$-catenin (Zhang et al. 2001). $\beta$-Catenin is a multifunctional protein located at the intracellular side of the cytoplasmic membrane that causes the malignant growth of colon (Mirabelli-Primidahl et al. 1999, Bienz \& Clevers 2000), renal (Bilim et al. 2000, Maiti et al. 2000), and pancreatic (Lowe et al. 2003, Heiser et al. 2008) tumors. $\beta$-Catenin activation also leads to breast (Lin et al. 2000, Geyer et al. 2010), anaplastic thyroid (Garcia-Rostan et al. 1999, Abbosh \& Nephew 2005), gastric (Ebert et al. 2003), liver (Thompson \& Monga 2007), ovarian (Morin 1999), endometrial (Morin 1999), and prostate cancers (Voeller et al. 1998, Cheshire \& Isaacs 2003). The gene that codes for $\beta$-catenin (CTNNB1) localizes to 3p21, a region implicated in tumor development (Kraus et al. 1994), which can also function as an oncogene (Wang et al. 2008).

These four cardiac hormones decrease the concentration of $\beta$-catenin up to $88 \%$ in human pancreatic cancer cells, up to $83 \%$ in human colorectal adenocarcinoma cells, and up to $73 \%$ in human renal adenocarcinoma cells (Skelton WP, IV, Skelton M \& Vesely DL, 2012, unpublished observations). ANP induces a decrease in the expression of total $\beta$-catenin, which is associated with a redistribution of $\beta$-catenin from nuclear and cytoplasmic compartments to cell-to-cell junction sites and is associated with a decrease in the proliferation of colon adenocarcinoma cells (Serafino et al. 2012). Each of these cardiac hormones inhibits proliferation and can even inhibit the proliferation of cancer cells that have escaped cell death when treated with the cardiac hormones (Vesely et al. 2003, 2005a). ANP also causes a significant downregulation of $c-M y c(M Y C)$ and cyclin D-1 gene transcriptions regulated by $\beta$-catenin (Serafino et al. 2012). $\beta$-Catenin appears to be the central target of the anticancer effects of the cardiac hormones since these hormones inhibit upstream RAS kinase, which activates $\beta$-catenin (Abbosh \& Nephew 2005), and downstream c-Jun $\mathrm{N}$-terminal kinase and VEGF, which are activated by $\beta$-catenin, as illustrated in Fig. 3 (Mann et al. 1999, Zhang et al. 2001).

\section{WNT signaling pathway}

The WNT signaling pathway is a signal transduction pathway that is enhanced in a variety of cancers (Bienz \& Clevers 2000, Polakis 2012). The origin of the name WNT comes from a portmanteau of Int (integration 1 gene in breast cancer) and Wg (wingless) in Drosophila, which has the best characterized WNT gene (Polakis 2012). The WNT gene family encodes for several signaling proteins, of which WNT-3a is a protein encoded in humans (Katoh 2002). WNT signaling is stimulated by RAS (Li et al. 2005) and VEGF pathways (Li et al. 2005). Both RAS and VEGF contribute to the pathobiology of colon cancer, in part, through the WNT pathway (Okada et al. 1998). KRAS and WNT pathways can cooperate to regulate the VEGF gene (Zhang et al. 2001). In human pancreatic carcinoma cells, WNT-3a maximally decreases $68 \%$ secondary to the four cardiac hormones (Skelton et al. 2013c). The four cardiac hormones also maximally reduce the concentration of WNT-3a by up to $53 \%$ in human colorectal adenocarcinoma cells (Skelton et al. 2013c). The complex interplay of WNT, RAS, and VEGF in causing cancer and maintaining its growth (Okada et al. 1998, Bienz \& Clevers 2000, Zhang et al. 2001, Katoh 2002, Li et al. 2005, Polakis 2012) is all targeted by the four cardiac hormones, which helps to explain their dramatic effects of eliminating up to $86 \%$ of human cancers growing in

Published by Bioscientifica Ltd 
mice and the fact that, once eliminated, these human cancers never return to the primary site in the lifespan of mice (Vesely et al. 2007a,b,c,d, Eichelbaum et al. 2008).

\section{Secreted frizzled-related protein-3}

Secreted frizzled-related protein-3 (sFRP-3) is an 300 a.a. glycoprotein (Lin et al. 1997, Rattner et al. 1997, Dann et al. 2001, Malbon 2004) that promotes renal cancer growth when injected into athymic mice (Hirata et al. 2010). sFRP-3 has been linked to tumor promotion in other types of cancers as well (Rubin et al. 2006). Bovolenta et al. (2008) have suggested that elevated sFRPs in various types of cancers may be a viable therapeutic target. ANP has effects through a frizzled-receptor which contains sFRP-3 (Xu \& Nusse 1998, Kawano \& Kypta 2003) mediated activation (Serafino et al. 2012). ANP and the frizzled receptor co-localize on the cell membrane within $30 \mathrm{~min}$ after ANP addition to culture medium (Serafino et al. 2012). We have found that vessel dilator, kaliuretic peptide, ANP, and LANP decrease the levels of sFRP-3 by $77-78 \%$ in human pancreatic cancer cells, $83-84 \%$ in human colorectal cancer cells, and $66-68 \%$ in human renal cancer cells (Skelton et al. 2013a). With respect to the mechanism by which the reduction of sFRP-3 levels by the cardiac hormones leads to their anticancer effects, their ability to inhibit sFRP-3, the active cysteine-rich domain (CRD) of the frizzled receptor (Rattner et al. 1997), blocks the propagation of the signal responsible for causing cancer cell growth.

\section{AKT}

AKT, also known as protein kinase $\mathrm{B}$ (PKB), is a serine/threonine protein kinase that has a key role in cell proliferation and in the growth of many types of cancer (Vivanco \& Sawyers 2002, Altomare \& Testa 2005, Hay 2005, Hennessy et al. 2005, Shaw \& Cantley 2006). The name AKT derives from the ' $\mathrm{Ak}^{\prime}$ ' mouse strain that develops spontaneous thymic lymphomas, where ' $\mathrm{t}$ ' stands for thymoma (Staal et al. 2007). AKT is overexpressed in colorectal cancer cells but not in normal colonic mucosa and hyperplastic polyps (Roy et al. 2002). ANP decreases the activation of AKT about twofold between 2 and $4 \mathrm{~h}$ of treatment in cell culture (Serafino et al. 2012). The other cardiac hormones also decrease AKT (Skelton et al. 2013b) with their results as follows: vessel dilator, kaliuretic peptide, and LANP reduce the concentration of AKT by 47, 45, and $46 \%$ in human colorectal cancer cells, by 60,61 , and $59 \%$ in human pancreatic carcinoma cells, and by 31,32 , and $31 \%$ in renal adenocarcinoma cells. There is a complex interplay of AKT, RAS, and VEGF in causing cancer and maintaining cancer cell growth (Gerber et al. 1998, Zhang et al. 2001, Vivanco \& Sawyers 2002, Altomare \& Testa 2005, Amaravadi \& Thompson 2005). This interplay is modified (inhibited) by these four cardiac hormones. There is a cross-talk between the activation of AKT and its inhibition by the cardiac hormones, which is summarized as follows: RAS activates AKT (Crowell et al. 2007). Growth factors such as EGF also activate RAS with a resultant downstream activation of AKT (Crowell et al. 2007). The effects of VEGFs on cancer growth and metastasis are mediated by binding to the VEGFR2 (KDR/Flk-1) receptor, which, in turn, activates the AKT pathway (Gerber et al. 1998). The four cardiac hormones inhibit each of these steps.

\section{STAT}

STATs are cytoplasmic transcription factors (Schindler et al. 1992, Yu \& Jove 2004) which are the final 'switches' that activate gene expression patterns that lead to malignancy (Schindler et al. 1992, Darnell 2002, Yu \& Jove 2004). STAT3 of the STATs is important in cancer formation (Bromberg \& Darnell 2002, Yu \& Jove 2004). STAT3 is overexpressed in a variety of human tumors and therefore could be a target for cancer treatment (Grandis et al. 1998, Song et al. 2003, Yu \& Jove 2004). The EGF receptor-mediated growth of squamous carcinoma cells is known to require STAT3 but not STAT1 (Grandis et al. 1998). Targeting STAT3 is also a strategy for reversing paclitaxel therapy resistance (Duan et al. 2006).

ERK $1 / 2$ activates (i.e. phosphorylates) STAT3 at serine 727 in response to growth factors (Chung et al. 1997). STAT3 is an excellent substrate for ERK kinases (Chung et al. 1997) and, as above, the cardiac hormones each inhibit ERK 1/2 kinases. Vessel dilator, LANP, kaliuretic peptide, and ANP decrease STAT3 by 88, 54, 55 , and $65 \%$ respectively in human small-cell lung cancers, and by $66,57,70$, and $77 \%$ in human pancreatic adenocarcinoma cells (Lane et al. 2012a). These cardiac hormones do not decrease STAT1 in either human smallcell lung cancer or pancreatic adenocarcinoma cells (Lane et al. 2012a). Thus, the four cardiac hormones are significant inhibitors of STAT3 but sparing STAT1, which suggests a specificity for the anticancer mechanism(s) of action of these hormones in human cancer cells (Lane et al. 2012a).

Published by Bioscientifica Ltd. 


\section{Four cardiac hormones cause cytotoxicity of human cancer cells but not of healthy cells}

One would surmise that the cardiac hormones may be cytotoxic rather than cytostatic, as cytostatic agents do not cause tumor shrinkage or elimination of cancers as the cardiac hormones do (Pitchumoni 1998, Vesely et al. 2007b,d, Eichelbaum et al. 2008). Cytotoxicity secondary to the cardiac hormones has been directly tested with a Cyto-Tox-Glo Cytotoxicity Assay (Promega), which is a cell-based luminescent assay that measures the extracellular activity of a distinct intracellular protease (dead-cell protease) when this protease is released from membranecompromised cells (Niles et al. 2007). The results of this assay directly correlate with the percentage of cells undergoing cytotoxicity (Niles et al. 2007). The four cardiac hormones have been found to cause cytotoxicity of up to $75 \%$ of human prostate cancer cells (Pi et al. 2011). There was no cytotoxicity of prostate and lung cells from healthy individuals exposed to the same concentrations of the cardiac hormones for an identical length of time (Pi et al. 2011). Thus, the four cardiac hormones cause cytotoxicity in human cancer cells while sparing healthy human cells.

\section{Four cardiac hormones cause cell death of human cancer cells but not of healthy cells}

Nuclear matrix proteins (NMPs) make up the internal structure (framework) of the nucleus and are associated with RNA synthesis (Hancock \& Boulikas 1982, Bouteille et al. 1983). Cell death releases soluble NMPs that can be detected in culture supernatant and other fluids containing dead and dying cells (Berrios et al. 1985, Zeitlin et al. 1987), and their measurement is useful to quantify cell death (Bouteille et al. 1983).

The cardiac hormones cause cell death in up to $36 \%$ of pancreatic adenocarcinoma cells and in up to $28 \%$ of prostate cancer cells over a concentration range of $100 \mathrm{pM}-$ $10 \mu \mathrm{M}$ as quantified by measuring NMP 4117 , which is a function of the number of dead or dying cells (Skelton et al. 2012). There was no cell death of healthy human prostate, kidney, or lung cells at the above concentrations (Skelton et al. 2012). Thus, these four cardiac hormones that cause the death of cancer cells spare healthy human prostate, lung, or kidney cells from cell death.

\section{Declaration of interest}

The patent to treat cancer with the cardiac hormones has been assigned to the University of South Florida, which has not licensed this patent to any commercial entity. There has been no pharmaceutical company funding or input into the studies described herein.

\section{Funding}

This work was supported in part by Merit Review Grants from the United States Department of Veterans Affairs, the James and Esther King Florida Biomedical Research Program, the Florida Department of Health, and the Mama Mare Breast Cancer Foundation. The contents of this article do not represent the views of the Department of Veterans Affairs or of the United States Government.

Author contribution statement

Dr Vesely is the sole author of this review.

\section{References}

Abbosh PH \& Nephew KP 2005 Multiple signaling pathways converge on $\beta$-catenin in thyroid cancer. Thyroid 15 551-561. (doi:10.1089/thy. 2005.15.551)

Altomare DA \& Testa JR 2005 Perturbations of the AKT signaling pathway in human cancer. Nature Reviews. Cancer 24 7455-7464.

Amaravadi R \& Thompson CB 2005 The survival kinases AKT and Pim as potential pharmacological targets. Journal of Clinical Investigation 115 2618-2624. (doi:10.1172/JCI26273)

Benjamin BA \& Peterson TV 1995 Effects of ProANF (31-67) on sodium excretion in conscious monkeys. American Journal of Physiology 269 R1351-R1355.

Berrios M, Osheroff N \& Fisher PA 1985 In situ localization of DNA topoisomerase II, a major polypeptide component of the Drosophila nuclear matrix fraction. PNAS 82 4142-4146. (doi:10.1073/pnas.82.12. 4142)

Bienz M \& Clevers H 2000 Linking colorectal cancer to Wnt signaling. Cell 103 311-320. (doi:10.1016/S0092-8674(00)00122-7)

Bilim V, Kawasaki T, Katagiri A, Wakatsuki S, Takahashi K \& Tomita Y 2000 Altered expression of $\beta$-catenin in renal cell cancer and transitional cell cancer with the absence of $\beta$-catenin gene mutations. Clinical Cancer Research 6 460-466.

Bost F, Dean N, McKay R \& Mercola D 1997 Activation of the Jun kinase/stress-activated protein kinase pathway is required for EGFautocrine stimulated growth of human A549 lung carcinoma cells. Journal of Biological Chemistry 272 33422-33429. (doi:10.1074/jbc.272. 52.33422)

Bost F, Potapova O, Liu C, Zhang YM, Charbono W, Dean N, McKay R \& Mercola D 1999a High frequency regression of established human prostate carcinoma PC3 xenografts by systemic treatment with antisense Jun kinase. Prostate 38 320-321.

Bost F, McKay R, Bost M, Potapova O, Dean NM \& Mercola D $1999 b$ Jun kinase-2 isoform is preferentially required for epidermal growth factor-induced proliferation of human A549 lung carcinoma. Molecular and Cellular Biology 19 1938-1949.

Bouteille M, Bouvier D \& Seve AP 1983 Heterogenity and territorial organization of the nuclear matrix and related structures. International Review of Cytology 83 135-182.

Bovolenta P, Esteve P, Ruiz JM, Cisneros E \& Lopez-Rios J 2008 Beyond WNT inhibition: new functions of secreted frizzled-related proteins in development and disease. Journal of Cell Science 121 737-746. (doi:10.1242/jcs.026096)

Brenner BM, Ballermann BJ, Gunning ME \& Zeidel ML 1990 Diverse biological actions of atrial natriuretic peptide. Physiological Reviews 70 665-699.

Breslin JW, Pappas PJ, Cerveira JJ, Hobson RW, II \& Duran WN 2003 VEGF increases endothelial permeability by separate signaling pathways involving ERK $1 / 2$ and nitric oxide. American Journal of Physiology $\mathbf{2 8 4}$ H92-H100.

Published by Bioscientifica Ltd. 
Bromberg J \& Darnell JE, Jr 2002 The role of STATs in transcriptional control and their impact on cellular function. Oncogene 19 2468-2473. (doi:10.1038/sj.onc.1203476)

Byrne AM, Bouchier-Hayes DJ \& Harmey JH 2005 Angiogenic and cell survival functions of vascular endothelial growth factor (VEGF). Journal of Cellular and Molecular Medicine 9 777-794. (doi:10.1111/ j.1582-4934.2005.tb00379.x)

Cataliotti A \& Burnett JC, Jr 2005 Natriuretic peptides: novel therapeutic targets in heart failure. Journal of Investigative Medicine 53 378-384. (doi:10.2310/6650.2005.53711)

Ceresa BP \& Pessin JE 1998 Insulin regulation of the RAS activation/ inactivation cycle. Molecular and Cellular Biochemistry 182 23-29. (doi:10.1023/A:1006819008507)

Cheshire DR \& Isaacs WB $2003 \beta$-Catenin signaling prostate cancer: an early perspective. Endocrine-Related Cancer 10 537-560. (doi:10.1677/ erc.0.0100537)

Chiou S \& Vesely DL 1995 Kaliuretic peptide: the most potent inhibitor of $\mathrm{Na}^{+}-\mathrm{K}^{+}$-ATPase of the atrial natriuretic peptides. Endocrinology 136 2033-2039. (doi:10.1210/en.136.5.2033)

Chung J, Uchida E, Grammer TC \& Blenis J 1997 STAT3 serine phosphorylation by ERK-dependent and -independent pathways negatively modulates its tyrosine phosphorylation. Molecular and Cellular Biology 17 6508-6516.

Crews CM, Alessandrini A \& Erikson RL 1992 The primary structure of MEK, a protein kinase that phosphorylates the ERK gene product. Science $\mathbf{2 5 8}$ 478-480. (doi:10.1126/science.1411546)

Crowell JA, Steele VE \& Fay JR 2007 Targeting the AKT protein kinase for cancer chemoprevention. Molecular Cancer Therapeutics 6 2139-2148. (doi:10.1158/1535-7163.MCT-07-0120)

Dann CE, Hsieh JC, Rattner A, Sharma D, Nathans J \& Leahy DJ 2001 Insights into WNT binding and signaling from the structures of two frizzled cysteine-rich domains. Nature 412 86-90. (doi:10.1038/ 35083601)

Darnell JE, Jr 2002 Transcription factors as targets for cancer therapy. Nature Reviews. Cancer 2 740-749. (doi:10.1038/nrc906)

Davis RJ 2000 Signal transduction by the JNK group of MAP kinases. Cell 103 239-252. (doi:10.1016/S0092-8674(00)00116-1)

De Palo EF, Woloszczuk W, Meneghetti M, De Palo CB, Nielsen HB \& Secher NH 2000 Circulating immunoreactive proANP (1-30) and proANP (31-67) in sedentary subjects and athletes. Clinical Chemistry 46 843-847.

Derijard R, Hibi M, Wu IH, Barrett T, Su B, Dent TL, Karin M \& David RJ 1994 JNK1-a protein kinase stimulated by UV-light and Ha-RAS that binds and phosphorylates the c-Jun activation domain. Cell $\mathbf{7 6}$ 1025-1037. (doi:10.1016/0092-8674(94)90380-8)

Dietz JR, Scott DY, Landon CS \& Nazian SJ 2001 Evidence supporting a physiological role for proANP (1-30) in the regulation of renal excretion. American Journal of Physiology 280 R1510-R1517.

Doanes AM, Hegland DD, Sethi R, Kovesdi I, Bruder JT \& Finkel T 1999 VEGF stimulates MAPK through a pathway that is unique for receptor tyrosine kinases. Biochemical and Biophysical Research Communications 255 545-548. (doi:10.1006/bbrc.1999.0227)

Duan Z, Foster R, Bell DA, Mahoney J, Wolak K, Vaidya A, Hempel C, Lee H \& Seiden MV 2006 Signal transducers and activators of transcription 3 pathway activation in drug-resistant ovarian cancer. Clinical Cancer Research 12 5055-5063. (doi:10.1158/1078-0432.CCR-06-0861)

Ebert MPA, Yu J, Hoffman J, Rocco A, Rocken C, Kahmann S, Muller O, Korc M, Sung JJ \& Malftheiner P 2003 Loss of $\beta$-catenin expression in metastatic gastric cancer. Journal of Clinical Oncology 2003 1708-1714. (doi:10.1200/JCO.2003.10.017)

Eichelbaum EJ, Vesely BA, Alli AA, Sun Y, Gower WR, Jr \& Vesely DL 2006 Four cardiac hormones decrease up to $82 \%$ of human medullary thyroid carcinoma cells within 24 hours. Endocrine $30325-332$ (doi:10.1007/s12020-006-0011-6)

Eichelbaum EJ, Sun Y, Alli AA, Gower WR, Jr \& Vesely DL 2008 Cardiac hormones and urodilatin eliminate up to $86 \%$ of human small-cell lung carcinomas in mice. European Journal of Clinical Investigation 38 562-570. (doi:10.1111/j.1365-2362.2008.01978.x)

Ferrara N 2004 Vascular endothelial growth factor: Basic science and clinical progress. Endocrine Reviews 25 581-611. (doi:10.1210/er. 2003-0027)

Folkman J 1971 Tumor angiogenesis: therapeutic implications. New England Journal of Medicine 295 1182-1186.

Folkman J 2007 Angiogenesis: an organizing principle for drug discovery? Nature Reviews. Drug Discovery 6 273-286. (doi:10.1038/nrd2115)

Franz M, Woloszcuk W \& Horl WH 2000 N-terminal fragments of the proatrial natriuretic peptide in patients before and after hemodialysis treatment. Kidney International 58 374-378. (doi:10.1046/j.1523-1755. 2000.00175.x)

Franz M, Woloszcuk W \& Horl WH 2001 Plasma concentration and urinary excretion of $\mathrm{N}$-terminal proatrial natriuretic peptides in patients with kidney diseases. Kidney International 59 1928-1934. (doi:10.1046/ j.1523-1755.2001.0590051928.x)

Garcia-Rostan G, Tallini G, Herrero A, D’Aquila TG, Carcangui ML \& Rimm DL 1999 Frequent mutation and nuclear localization of $\beta$-catenin in anaplastic thyroid carcinoma. Cancer Research 59 1811-1815.

Gardner DG, Kovacic-Milivojevic BK \& Garmai M 1997 Molecular biology of the natriuretic peptides. In Atrial Natriuretic Peptides, pp 15-38. Ed DL Vesely. Trivandum, India: Research Signpost.

Gerber HP, McMurtrey A, Kowalski J, Yan M, Keyt BA, Dixit V \& Ferrara N 1998 Vascular endothelial growth factor regulates endothelial cell survival through the phosphatidylinositol 3'-kinast/AKT signal transduction pathway: requirement for FLK-1/KDR activation. Journal of Biological Chemistry 273 30336-30343. (doi:10.1074/jbc.273. 46.30336)

Geyer FC, Lacroix-Triki M, Savage K, Arnedos M, Lambros MB, MacKay A, Natrajan R \& Reis-Filho JS $2010 \beta$-Catenin pathway activation in breast cancer is associated with triple-negative phenotype but not with CTNNB1 mutation. Modern Pathology 24 209-231. (doi:10.1038/ modpathol.2010.205)

Gower WR, Jr, Vesely BA, Alli AA \& Vesely DL 2005 Four peptides decrease human colon adenocarcinoma cell number and DNA synthesis via guanosine $3^{\prime}, 5^{\prime}$-cyclic monophosphate. International Journal of Gastrointestinal Cancer 36 77-87. (doi:10.1385/IJGC:36:2:77)

Gower WR, Carter GM, McAfee Q \& Solivan SM 2006 Identification, regulation and anti-proliferative role of the NPR-C receptor in gastric epithelial cells. Molecular and Cellular Biochemistry 293 103-118. (doi:10.1007/s11010-006-9234-3)

Grandis J, Drenning SD, Chakraborty A, Zhou MY, Zeng Q, Pitt AS \& Tweardy DJ 1998 Requirement of STAT3 but not STAT1 activation for epidermal growth factor receptor-medicated cell grown in vitro. Journal of Clinical Investigation 102 1385-1392. (doi:10.1172/JCI3785)

Gunning ME, Brady HR, Otuechere G, Brenner BM \& Ziedel ML 1992 Atrial natriuretic peptide (31-67) inhibits $\mathrm{Na}$ transport in rabbit inner medullary collecting duct cells: role of prostaglandin $\mathrm{E}_{2}$. Journal of Clinical Investigation 89 1411-1417. (doi:10.1172/JCI115730)

Gupta I, Kshirsagar S, Li W, Gui L, Ramakrishnan S, Gupta P, Law PW \& Hebbel RP 1999 VEGF prevents apoptosis of human microvascular endothelial cells via opposing effects on MAPK/ERK and SAPK/JNK signaling. Experimental Cell Research 247 495-504. (doi:10.1006/excr. 1998.4359)

Hancock R \& Boulikas T 1982 Functional organization in the nucleus. International Review of Cytology 79 165-214.

Hay N 2005 The AKT-mTOR tango and its relevance to cancer. Cancer Cell 8 179-183. (doi:10.1016/j.ccr.2005.08.008)

Heasley LE \& Han SY 2006 JNK regulation of oncogenesis. Molecules and Cells 21 167-173.

Heiser PW, Cano DA, Landsman L, Kim GE, Kench JG, Klimstra DS, Taketo MM, Biankin AV \& Hebrok M 2008 Stabilization of $\beta$-catenin induces pancreas tumor formation. Gastroenterology 135 1288-1300. (doi:10.1053/j.gastro.2008.06.089) 
Hennessy BT, Smith DL, Ram PT, Lu Y \& Mills GB 2005 Exploiting the PI3K/AKT pathway for cancer drug discovery. Nature Reviews. Drug Discovery 4 988-1004. (doi:10.1038/nrd1902)

Hirata H, Hinoda Y, Ueno K, Majid S, Saini S \& Dahiya R 2010 Role of secreted frizzled-related protein 3 in human renal cell carcinoma. Cancer Research 70 1896-1905. (doi:10.1158/0008-5472.CAN-09-3549)

Hoeben A, Landuyt B, Highley MS, Wilders H, Van Oosterom AT \& DeBruijn EA 2004 Vascular endothelium growth factor. Pharmacological Reviews 56 549-580. (doi:10.1124/pr.56.4.3)

Hunter EMF, Kelly PA, Prowse C, Woods FJ \& Lowry PJ 1998 Analysis of peptides derived from pro atrial natriuretic peptides that circulate in man and increase in heart disease. Scandinavian Journal of Clinical and Laboratory Investigation 58 205-216. (doi:10.1080/ 00365519850186599)

Juneja J, Cushman I \& Casey PJ 2011 G12 signaling through c-Jun $\mathrm{NH}_{2}$-terminal kinase promotes breast cancer cell invasion. PLoS ONE 6 e26085. (doi:10.1371/journal.pone.0026085)

Kamada T \& Feramisco JR 1984 Epidermal growth factor stimulates guanine nucleotide-binding activity and phosphorylation of $n s$ oncogene proteins. Nature 310 147-150. (doi:10.1038/310147a0)

Katoh M 2002 Regulation of WNT3 and WNT3A mRNAs in human cancer cell lines NT2, MCF-7, and MKN45. International Journal of Oncology 20 373-377.

Kawano Y \& Kypta R 2003 Secreted antagonists of the WNT signalling pathway. Journal of Cell Science 116 2627-2634. (doi:10.1242/jcs.00623)

Kraus C, Liehr T, Hulsken J, Behrens J, Birchmeier W, Grzeschik KH \& Ballhausen WG 1994 Location of the human $\beta$-catenin gene (CTNNB1) to 3p21; a region implicated in tumor development. Genomics $\mathbf{2 3}$ 272-274. (doi:10.1006/geno.1994.1493)

Kyriakas JM, Banerjee P, Nikolakaki E, Dai TA, Rubie EA, Ahmad MF, Avruch J \& Woodgett JR 1994 The stress-activated protein-kinase subfamily of c-Jun kinases. Nature 369 156-160. (doi:10.1038/ 369156a0)

Lainchbury J, Richards AM \& Nicholls MG 1997 Brain natriuretic peptide in heart failure. In Atrial Natriuretic Peptides, pp 151-158. Ed. DL Vesely. Trivandrum, India: Research Signpost.

Lane ML, Frost CD, Nguyen JP, Skelton WP, IV, Skelton M \& Vesely DL $2012 a$ Potent selective inhibition of STAT3 versus STAT1 by cardiac hormones. Molecular and Cellular Biochemistry 371 209-215. (doi:10.1007/s11010-012-1437-1)

Lane ML, Santana O, Frost CD, Nguyen J, Guerrero J, Skelton WP, IV, Skelton M \& Vesely DL 2012b Cardiac hormones are c-Jun-N-terminal kinase 2-inhibiting peptides. Anticancer Research 32 721-726.

Lenz A, Sun Y, Eichelbaum EJ, Skelton WP, IV, Pi G \& Vesely DL 2010 Twice weekly intravenous treatment of pancreatic cancer with atrial natriuretic peptide and vessel dilator. In Vivo 24 125-130.

Li J, Mizukami Y, Zhang X, Jo W-S \& Chung DC 2005 Oncogenic KRAS stimulates WNT signaling in colon cancer through inhibition of GSK-3 3 . Gastroenterology 128 1907-1918. (doi:10.1053/j.gastro.2005.02.067)

Lin K, Wang S, Julius MA, Kitajewski J, Moos M, Jr \& Luyten FP 1997 The cysteine-rich frizzled domain of Frzb-1 is required and sufficient for modulation of WNT signaling. PNAS 94 11196-11200. (doi:10.1073/ pnas.94.21.11196)

Lin SY, Xia W, Wang JC, Kwong KY, Spohn B, Wen Y, Pestell RG \& Hung MC $2000 \beta$-Catenin, a novel prognostic marker for breast cancer: its roles in cyclin D1 expression and cancer progression. PNAS $\mathbf{9 7}$ 4262-4266. (doi:10.1073/pnas.060025397)

Liotta LA, Kleinerman J \& Saidel GM 1974 Quantitative relationships of intravascular tumor cells, tumor vessels, and pulmonary metastases following tumor implantation. Cancer Research 34 997-1004.

Lowe AW, Olsen M, Hao Y, Lee SP, Lee KT, Chen X, Vanderijn M \& Brown PO 2003 Gene expression patterns in pancreatic tumor, cells and tissues. Annals of Surgical Oncology 10 284-290. (doi:10.1245/ASO.2003. 05.003)

Maiti S, Alam R, Amos CI \& Huff V 2000 Frequent association of $\beta$-catenin and WTI mutations in Wilms tumors. Cancer Research 60 6288-6292.
Malbon CC 2004 Frizzleds: new members of the superfamily of G-protein-coupled receptors. Frontiers in Bioscience 9 1048-1058. (doi:10.2741/1308)

Mann B, Gelos M, Siedow A, Hanski ML, Gratchev A, Ilyas M, Bodmer WF, Moyer MP, Riecken EO, Burh HJ et al. 1999 Target genes of $\beta$-catenin-T cell factor/lymphoid-enhancer-factor signaling in human colorectal carcinomas. PNAS 96 1603-1608. (doi:10.1073/pnas.96.4.1603)

Martin DR, Pevanouse JB, Trigg DJ, Vesely DL \& Buerkert JE 1990 Three peptides from the ANF prohormone $\mathrm{NH}_{2}$-terminus are natriuretic and/or kaliuretic. American Journal of Physiology 258 F1401-F1408.

McCubrey JA, Steelman LS, Chappell WH, Abrams SL, Wong EWT, Chang F, Lehmann B, Terrian DM, Milella M, Tafuri A et al. 2007 Roles of the RAF/MEK/ERK pathway in cell growth, malignant transformation and drug resistance. Biochimica et Biophysica Acta 1773 1263-1284. (doi:10.1016/j.bbamcr.2006.10.001)

McCubrey JA, Milella M, Tafuri A, Martelli AM, Lunghi P, Bonati A, Cervello M, Lee JT \& Steelman LS 2008 Targeting the RAF/MEK/ERK pathway with small-molecule inhibitors. Current Opinion in Investigational Drugs 9 614-633.

McMahon G 2000 VEGF receptor signaling in tumor angiogenesis. Oncologist 5 S3-S10. (doi:10.1634/theoncologist.5-suppl_1-3)

Meadows KN, Bryant P \& Pumiglia K 2001 Vascular endothelial growth factor induction of the angiogenic phenotype required RAS activation. Journal of Biological Chemistry 276 49289-49298. (doi:10.1074/jbc. M108069200)

Medema RS, DeVries-Smith AMM, Van der Zon GCM, Maasen JA \& Bos JL 1992 Ras activation by insulin and epidermal growth factor through enhanced exchange of guanine nucleotides on $\mathrm{p}^{21}$ ras. Molecular and Cellular Biology 13 155-162.

Minden A, Lin A, McMahon M, Lange-Carter C, Derijard B, Davis RJ, Johnson GL \& Karin M 1994 Differential activation of ERK and JNK mitogen-activated protein kinases by RAF-1 and MEKK. Science 266 1719-1723. (doi:10.1126/science.7992057)

Mirabelli-Primidahl L, Gryfe R, Kim H, Millar A, Luceri C, Dale D, Holowaty E, Bayat B, Gallinger S \& Redston M 1999 ß-Catenin mutations are specific for colorectal carcinomas with microsatellite instability but occur in endometrial carcinomas irrespective of mutator pathway. Cancer Research 59 3346-3351.

Morin PJ 1999 $\beta$-Catenin signaling and cancer. BioEssays 21 1021-1030. (doi:10.1002/(SICI)1521-1878(199912)22:1 < 1021::AID-BIES6 > 3.0. $\mathrm{CO} ; 2-\mathrm{P})$

Nguyen JP, Frost CD, Lane ML, Skelton WP, IV, Skelton M \& Vesely DL 2012 Novel dual inhibitors of vascular endothelial growth factor and VEGFR2 receptor. European Journal of Clinical Investigation $\mathbf{4 2}$ 1061-1067. (doi:10.1111/j.1365-2362.2012.02695.x)

Niles AL, Moravec RA, Hesselberth E, Scurria MA, Daily WJ \& Riss TL 2007 A homogenous assay to measure live and dead cells in the same sample by detecting different protease markers. Analytical Biochemistry $\mathbf{3 6 6}$ 197-206. (doi:10.1016/j.ab.2007.04.007)

Okada R, Rak JW, Croix BS, Lieubeau B, Kaya M, Roncari L, Shirasawa S, Sasazuki T \& Kerbel RS 1998 Impact of oncogenes in tumor angiogenesis: mutant KRAS up-regulation of vascular endothelial growth factor/vascular permeability factor is necessary, but not sufficient for tumorigenicity of human colorectal carcinoma cells. PNAS 95 3609-3614. (doi:10.1073/pnas.95.7.3609)

Pi GE, Skelton WP, IV \& Vesely DL 2011 Four cardiac hormones cause cytotoxicity of human cancer cells but not of healthy cells. Cancer Therapy 8 44-50.

Pitchumoni CS 1998 Pancreatic disease. In Internal Medicine, 5th edn, pp 2233-2247. Ed JH Stein. St Louis: Mosby.

Polakis P 2012 Drugging WNT signaling in cancer. EMBO Journal 31 2737-2746. (doi:10.1038/emboj.2012.126)

Qui MS \& Green ST 1991 NGF and BGF rapidly activate p21 ras in PC12 cells by distinct, convergent pathways involving tyrosine phosphorylation. Neuron 7 937-946. (doi:10.1016/0896-6273(91)90339-2) 
Rashed HM, Su H \& Patel TB 1993 Atrial natriuretic peptide inhibits growth of hepatoblastoma (HEP G2) cells by means of activation of clearance receptors. Hepatology 17 677-684. (doi:10.1002/hep.1840170423)

Rattner A, Hsieh JC, Smallwood PM, Gilbert DJ, Copeland NG, Jenkins NA \& Nathans J 1997 A family of secreted proteins contains homology to the cysteine-rich ligand-binding domain of frizzled receptors. PNAS 94 2859-2863. (doi:10.1073/pnas.94.7.2859)

Rosette C \& Karin M 1996 Ultraviolet light and osmotic stress: activation of the JNK cascade through multiple growth factor and cytokine receptors. Science 274 1194-1197. (doi:10.1126/science.274.5290.1194)

Roy HK, Olusola BF, Clemens DL, Karolski WJ, Ratashak A, Lynch HT \& Smyrk TC 2002 AKT proto-oncogene overexpression is an early event during sporadic colon carcinogenesis. Carcinogenesis 23 201-205. (doi:10.1093/carcin/23.1.201)

Rubin JS, Barshishat-Kupper M, Feroze-Merzoup F \& Xi ZF 2006 Secreted WNT antagonists are tumor suppressors: pro and con. Frontiers in Bioscience 11 2093-2105. (doi:10.2741/1952)

Satoh T, Endo M, Nakaruku M, Akiyana T, Yamamoto T \& Kazio Y 1990 Accumulation of p21 ras GTP in response to stimulation with epidermal growth factor and oncogene products with tyrosine activity. PNAS 87 7926-7929. (doi:10.1073/pnas.87.20.7926)

Schindler C, Shuai K, Prezioso VR \& Darnell JE, Jr 1992 Interferondependent tyrosine phosphorylation of a latent cytoplasmic transcription factor. Science 257 809-813. (doi:10.1126/science.1496401)

Schlessinger J 2000 Cell signaling by receptor tyrosine kinases. Cell $\mathbf{1 0 3}$ 211-225. (doi:10.1016/S0092-8674(00)00114-8)

Scholl FA, Dumesic PA \& Khavari PA 2005 Effects of active MEK 1 expression in vivo. Cancer Letters 230 1-5. (doi:10.1016/j.canlet.2004. 12.013)

Scotland RS, Ahluwalia A \& Jobbs AJ 2005 C-type natriuretic peptide in vascular physiology and disease. Pharmacology \& Therapeutics 105 85-93. (doi:10.1016/j.pharmthera.2004.08.011)

Sebolt-Leopold JS 2008 Advances in the development of cancer therapeutics directed against the RAS mitogen-activated protein kinase pathway. Clinical Cancer Research 14 3651-3656. (doi:10.1158/10780432.CCR-08-0333)

Serafino A, Moroni N, Psaila R, Zonfrillo M, Andreola F, Wannenes F, Mercuri L, Rasi G \& Pierimarci P 2012 Anti-proliferative effect of atrial natriuretic peptide on colorectal cancer cells: evidence for an Akt-mediated cross-talk between NHE-1 activity and Wnt/ $\beta$-catenin signaling. Biochimica et Biophysica Acta 1822 1004-1018. (doi:10.1016/ j.bbadis.2012.02.016)

Shaw RJ \& Cantley LC 2006 Ras, PI(3)K and mTOR signaling controls tumor cell growth. Nature $\mathbf{4 4 1}$ 424-430. (doi:10.1038/nature04869)

Skelton WP, IV, Pi GE \& Vesely DL 2012 Four cardiac hormones cause death of human cancer cells but not of healthy cells. Anticancer Research 31 395-402.

Skelton WP, IV, Skelton M \& Vesely DL 2013a Cardiac hormones are potent inhibitors of secreted frizzled related protein-3 in human cancer cells. Experimental and Therapeutic Medicine 5 475-478.

Skelton WP, IV, Skelton M \& Vesely DL $2013 b$ Inhibition of AKT in human pancreatic, renal and colorectal cancer cells by four cardiac hormones. Anticancer Research 33 785-790.

Skelton WP, IV, Skelton M \& Vesely DL 2013 Cardiac hormones are novel inhibitors of Wnt-3a in human cancer cells. Cancer Therapy 9 24-29.

Song L, Turkson J, Karras JG, Jove R \& Haura EB 2003 Activation of STAT3 by receptor tyrosine kinases and cytokinases regulates survival in human non-small-cell carcinoma cells. Oncogene 22 4150-4165. (doi:10.1038/sj.onc.1206479)

Staal SP, Hartley JW \& Rowe SP 2007 Isolation of transforming murine leukemia viruses from mice with a high incidence of spontaneous lymphoma. PNAS 74 3065-3067. (doi:10.1073/pnas.74.7.3065)

Sun Y, Eichelbaum EJ, Wang H \& Vesely DL 2006a Vessel dilator and kaliuretic peptide inhibit activation of ERK $1 / 2$ in human prostate cancer cells. Anticancer Research 26 3217-3222.
Sun Y, Eichelbaum EJ, Wang H \& Vesely DL 2006 $b$ Atrial natriuretic peptide and long acting natriuretic peptide inhibit ERK $1 / 2$ in prostate cancer cells. Anticancer Research 26 4143-4148.

Sun Y, Eichelbaum EJ, Wang H \& Vesely DL 2007a Vessel dilator and kaliuretic peptide inhibit MEK $1 / 2$ activation in human prostate cancer cells. Anticancer Research 27 1387-1392.

Sun Y, Eichelbaum EJ, Wang H \& Vesely DL 2007 $b$ Atrial natriuretic peptide and long acting natriuretic peptide inhibit MEK $1 / 2$ activation in human prostate cancer cells. Anticancer Research 27 3813-3818.

Sun Y, Eichelbaum EJ, Wang H \& Vesely DL 2007c Insulin and epidermal growth factor activation of ERK $1 / 2$ and DNA synthesis is inhibited by four cardiac hormones. Journal of Cancer Molecules 3 113-120.

Sun Y, Eichelbaum EJ, Skelton WP, IV, Lenz A, Regales N, Wang H \& Vesely DL $2009 a$ Vessel dilator and kaliuretic peptide inhibit RAS in human prostate cancer cells. Anticancer Research 29 971-975.

Sun Y, Eichelbaum EJ, Lenz A, Skelton WP, IV, Wang H \& Vesely DL 2009b Atrial natriuretic peptide and long-acting natriuretic peptide inhibit RAS in human prostate cancer cells. Anticancer Research 29 1889-1893.

Sun Y, Eichelbaum EJ, Lenz A, Wang H \& Vesely DL 2009c Four cardiac hormones inhibit insulin's mitogenic action via inhibiting RAS. Cancer Therapy 7 367-372.

Sun Y, Eichelbaum EJ, Lenz A, Wang H \& Vesely DL 2010 Epidermal growth factor's activation of RAS is inhibited by four cardiac hormones. European Journal of Clinical Investigation 40 408-413. (doi:10.1111/ j.1365-2362.2010.02283.x)

Thompson MD \& Monga SPS 2007 WNT/ $\beta$-catenin signaling in liver health and disease. Hepatology 45 1298-1305. (doi:10.1002/hep.21651)

Vesely DL 1977 Signal transduction: activation of guanylate cyclase-cyclic guanosine- $3^{\prime}, 5^{\prime}$ monophosphate system by hormones and free radicals. American Journal of the Medical Sciences 314 311-323. (doi:10.1097/ 00000441-199711000-00008)

Vesely DL 1992 Atrial Natriuretic Hormones, pp 1-256. Englewood Cliffs, New Jersey: Prentice Hall.

Vesely DL 2002 Atrial natriuretic peptide prohormone gene expression: hormones and diseases that upregulate its expression. IUBMB Life $\mathbf{5 3}$ 153-159. (doi:10.1080/15216540212336)

Vesely DL 2003 Natriuretic peptides and acute renal failure (review). American Journal of Physiology 285 F167-F177.

Vesely DL, Norris JS, Walters JM, Jespersen RR \& Baeyens DA 1987 Atrial natriuretic prohormone peptides 1-30, 31-67 and 79-98 vasodilate the aorta. Biochemical and Biophysical Research Communications 148 1540-1548. (doi:10.1016/S0006-291X(87)80307-8)

Vesely DL, Norsk P, Winters CJ, Rico DM, Sallman AL \& Epstein M 1989 Increased release of the $\mathrm{N}$-terminal and $\mathrm{C}$-terminal portions of the prohormone of atrial natriuretic factor during immersion-induced central hypervolemia in normal humans. Proceedings of the Society for Experimental Biology and Medicine 192 230-235.

Vesely DL, Douglass MA, Dietz JR, Gower WR, Jr, McCormick MT, Rodriguez-Paz G \& Schocken DD 1994a Three peptides from the atrial natriuretic factor prohormone amino terminus lower blood pressure and produce diuresis, natriuresis, and/or kaliuresis in humans. Circulation 90 1129-1140. (doi:10.1161/01.CIR.90.3.1129)

Vesely DL, Douglass MA, Dietz JR, Giordano AT, McCormick MT, Rodriguez-Paz G \& Schocken DD $1994 b$ Negative feedback of atrial natriuretic peptides. Journal of Clinical Endocrinology and Metabolism $\mathbf{7 8}$ 1128-1134. (doi:10.1210/jc.78.5.1128)

Vesely DL, Dietz JR, Parks JR, Baig M, McCormick MT, Cintron G \& Schocken DD 1998 Vessel dilator enhances sodium and water excretion and has beneficial hemodynamic effects in persons with congestive heart failure. Circulation 98 323-329. (doi:10.1161/01.CIR.98.4.323)

Vesely BA, McAfee Q, Gower WR, Jr \& Vesely DL 2003 Four peptides decrease the number of human pancreatic adenocarcinoma cells. European Journal of Clinical Investigation 33 998-1005. (doi:10.1046/j. 1365-2362.2003.01262.x)

Vesely DL, Clark LC, Garces AH, McAfee QW, Soto J \& Gower WR, Jr 2004 Novel therapeutic approach for cancer using four cardiovascular 
hormones. European Journal of Clinical Investigation 34 674-682. (doi:10.1111/j.1365-2362.2004.01402.x)

Vesely BA, Alli AA, Song S, Gower WR, Jr, Sanchez-Ramos J \& Vesely DL $2005 a$ Four peptide hormones specific decrease (up to 97\%) of human prostate carcinoma cells. European Journal of Clinical Investigation $\mathbf{3 5}$ 700-710. (doi:10.1111/j.1365-2362.2005.01569.x)

Vesely BA, Song S, Sanchez-Ramos J, Fitz SR, Alli A, Solivan SM, Gower WR, Jr $\&$ Vesely DL $2005 b$ Five cardiac hormones decrease the number of human small-cell lung cancer cells. European Journal of Clinical Investigation 35 388-398. (doi:10.1111/j.1365-2362.2005.01501.x)

Vesely BA, Song S, Sanchez-Ramos J, Fitz SR, Solivan SR, Gower WR, Jr \& Vesely DL $2005 c$ Four peptide hormones decrease the number of human breast adenocarcinoma cells. European Journal of Clinical Investigation 35 60-69. (doi:10.1111/j.1365-2362.2005.01444.x)

Vesely BA, Alli A, Song S, Sanchez-Ramos J, Fitz SR, Gower WR, Jr \& Vesely DL 2006a Primary malignant tumors of the heart: four cardiovascular hormones decrease the number and DNA synthesis of human angiosarcoma cells. Cardiology 105 226-233. (doi:10.1159/ 000091816)

Vesely BA, Fitz SR, Gower WR, Jr \& Vesely DL $2006 b$ Vessel dilator: most potent of the atrial natriuretic peptides in decreasing the number and DNA synthesis of human squamous lung cancer cells. Cancer Letters 233 226-231. (doi:10.1016/j.canlet.2005.03.024)

Vesely BA, Eichelbaum EJ, Alli AA, Sun Y, Gower WR, Jr \& Vesely DL $2006 c$ Urodilatin and four cardiac hormones decrease human renal carcinoma cell number. European Journal of Clinical Investigation 36 810-819. (doi:10.1111/j.1365-2362.2006.01721.x)

Vesely BA, Eichelbaum EJ, Alli AA, Sun Y, Gower WR, Jr \& Vesely DL 2007a Four cardiac hormones eliminate 4 -fold more human glioblastoma cells than green mamba snake peptide. Cancer Letters 254 94-101. (doi:10. 1016/j.canlet.2007.02.015)

Vesely BA, Eichelbaum EJ, Alli AA, Sun Y, Gower WR, Jr \& Vesely DL $2007 b$ Four cardiac hormones cause cell death in $81 \%$ of human ovarian adenocarcinoma cells. Cancer Therapy 5 97-104.

Vesely DL, Eichelbaum EJ, Sun Y, Alli AA, Vesely BA, Luther SL \& Gower WR, Jr 2007 c Elimination of up to $80 \%$ of human pancreatic adenocarcinomas in athymic mice by cardiac hormones. In Vivo 21 445-452.

Vesely DL, Vesely BA, Eichelbaum EJ, Sun Y, Alli AA \& Gower WR, Jr 2007d Four cardiac hormones eliminate up to two-thirds of human breast cancers in athymic mice. In Vivo 21 973-978.

Villarreal D, Reams GP, Taraben A \& Freeman RH 1999 Hemodynamic and renal effects of proANF 31-67 in hypertensive rats. Proceedings of the Society for Experimental Biology and Medicine 221 166-170. (doi:10.1046/ j.1525-1373.1999.d01-71.x)

Vivanco I \& Sawyers CL 2002 The phosphatidylinositol 3-kinase-AKT pathway in human cancer. Nature Reviews. Cancer 2 489-501. (doi:10.1038/nrc839)

Voeller JH, Trucia CI \& Gelmann EP 1998 $\beta$-Catenin mutations in human prostate cancer. Cancer Research $\mathbf{5 8} 2520-2523$.
Waldman SE, Rapoport RM \& Murad F 1984 Atrial natriuretic factor selectively activates membranous guanylate cyclase and elevates cyclic GMP in rat tissues. Journal of Biological Chemistry 259 14332-14334.

Wang X, Goode EL, Fredericksen ZA, Vierkant RA, Pankratz VS, Liu-Mares W, Rider DN, Vachon CM, Cerhan JR, Olson JE et al. 2008 Association of genetic variation in genes implicated in the $\beta$-catenin destruction complex with risk of breast cancer. Cancer Epidemiology, Biomarkers, and Prevention 17 2101-2108. (doi:10.1158/1055-9965.EPI-08-0134)

Wang K, Jiang YZ, Chen DB \& Zheng J 2009 Hypoxia enhances FGF-2 and VEGF stimulated human placental artery endothelial cell proliferation: roles of MEK-1/2/ERK1-2 and PI3K/AKT1 pathways. Placenta 30 1045-1051. (doi:10.1016/j.placenta.2009.10.007)

Wang X, Raulji P, Mohapatra SS, Patel R, Hellermann G, Kong X, Vera PD, Meyer-Siegler KL, Coppola D \& Mohapatra S 2011 Natriuretic peptide receptor A as a novel target for prostate cancer. Molecular Cancer 1056. (doi:10.1186/1476-4598-10-56)

Winters CJ, Sallman AL, Baker BJ, Meadows J, Rico DM \& Vesely DL 1989 The N-terminus and a 4000 molecular weight peptide from the mid portion of the N-terminus of the atrial natriuretic factor prohormone each circulate in humans and increase in congestive heart failure. Circulation 80 438-449. (doi:10.1161/01.CIR.80.3.438)

Wolff RA, Crane CH, Li D \& Evans DB 2010 Neoplasms of the exocrine pancreas. In Cancer Medicine, 8th edn, pp 1144-1171. Eds WK Hong, RC Bast Jr, WN Hait, DW Kufe, RE Pollock, RR Weichselbaum, JF Holland \& E Frei III. London: BC Decker, Inc.

Wu J, Harrison JK, Dent P, Lynch KR, Weber MJ \& Sturgill TW 1993 Identification and characterization of a new mammalian mitogenactivated protein kinase kinase MKK-2. Molecular and Cellular Biology 13 4539-4548.

Xia L, Dickens M, Raingeaud J, David RJ \& Greenberg ME 1995 Opposing effects of ERK and JNK-p38 MAP kinases on apoptosis. Science 270 1326-1331. (doi:10.1126/science.270.5240.1326)

Xu YK \& Nusse R 1998 The frizzled CRD domain is conserved in diverse proteins including several receptor tyrosine kinases. Current Biology 8 R405-R406. (doi:10.1016/S0960-9822(98)70262-3)

Yang YM, Bost F, Charbono W, Dean N, McKay R, Rhim JS, Depatie C \& Mercola D 2003 c-Jun NH(2)-terminal kinase mediates proliferation and tumor growth of human prostate carcinoma. Clinical Cancer Research 9 391-401.

Yu H \& Jove R 2004 The STATs of cancer: new molecular targets come of age. Nature Reviews. Cancer 4 450-456. (doi:10.1038/nrc1275)

Zeidel ML 1995 Regulation of collecting duct $\mathrm{Na}^{+}$reabsorption by ANP 31-67. Clinical and Experimental Pharmacology \& Physiology 22 121-124. (doi:10.1111/j.1440-1681.1995.tb01967.x)

Zeitlin S, Parent A, Silverstein S \& Efstratiadis J 1987 Pre mRNA splicing and the nuclear matrix. Molecular and Cellular Biology 7 111-120.

Zhang X, Gaspard JP \& Chung DC 2001 Regulation of vascular endothelial growth factor by the WNT and KRAS pathways in colonic neoplasia. Cancer Research 61 6050-6054.

Received in final form 21 March 2013

Accepted 25 March 2013

Made available online as an Accepted Preprint

26 March 2013 http://erc.endocrinology-journals.org

DOI: 10.1530/ERC-13-0054
(C) 2013 Society for Endocrinology Printed in Great Britain
Published by Bioscientifica Ltd. 